\title{
The association between serum metalloproteinase concentration, obesity, and hormone levels in reproductive-aged women
}

\author{
Wpływ otyłości i zmian hormonalnych na stężenie osoczowych metaloproteinaz \\ u miesiączkujących kobiet
}

\author{
Barbara Grzechocińska ${ }^{1}$, Filip Dąbrowski ${ }^{1}$, Janusz Sierdzinski ${ }^{2}$, Anna Cyganek ${ }^{1}$, Mirosław Wielgoś ${ }^{1}$ \\ ${ }^{1} 1^{\text {st }}$ Department of Obstetrics and Gynaecology, Medical University of Warsaw, Warsaw, Poland \\ ${ }^{2}$ Department of Medical Informatics and Telemedicine, Medical University of Warsaw, Warsaw, Poland
}

\begin{abstract}
Introduction: Increased levels and activity of some matrix metalloproteinases (MMPs) are described in obesity-related vascular diseases. Factors that influence MMP blood concentration are still being investigated. This research aims to evaluate the concentration of most types of MMPs: collagenases (MMP-1, -3, -8, -13), matrilysin (MMP-7), gelatinase (MMP-9), and metalloelastase (MMP-12) in serum of women in reproductive age in relation with their body mass index (BMI), age, oestradiol, and progesterone concentrations.

Material and methods: Blood samples were taken from 54 healthy reproductive-aged women with normal menstrual cycles. The weight and height of all women were measured, and body mass index (BMI) was calculated. Concentration of MMP-1, -3, -7, -8, -9, -12, and MMP-13 was evaluated using a Procarta Immunoassay Kit. Serum concentrations of oestradiol and progesterone were evaluated by immunochemiluminescence (32 in the proliferative and 20 in the secretory phase of menstrual cycle). The results of the study were statistically calculated using Pearson, Spearman, and Kruskal-Wallis tests.

Results: Positive correlation between MMP-7, $-8,-9,-12$, and -13 levels and BMI was demonstrated. Significantly higher concentrations of MMPs were found especially in obese women compared to women with normal BMI. In healthy, regularly menstruating premenopausal women, MMP levels did not correlate with oestradiol and progesterone concentrations.

Conclusions: The results suggest that body mass can influence MMP serum concentration in women with regular menstrual cycles. (Endokrynol Pol 2019; 70 (1): 49-56)

Key words: MMP; obesity; cardiovascular risk; oestradiol; progesterone

Streszczenie

Wstęp: $\mathrm{W}$ doniesieniach opisuje się zwiększone stężenia i aktywności niektórych metaloproteinaz macierzy (MMP) w chorobach naczyniowych związanych z otyłością. Czynniki wpływające na stężenia MMP we krwi są wciąż tematem badań. Niniejsze badanie przeprowadzono w celu oceny stężeń większości typów MMP: kolagenaz (MMP-1, -3, -8, -13), matrylizyny (MMP-7), gelatynazy (MMP-9) i metaloelastazy (MMP-12) w surowicy kobiet w wieku rozrodczym w odniesieniu do wskaźnika masy ciała (body mass index, BMI) i wieku oraz stężeń estradiolu i progesteronu.

Materiał i metody: Pobrano próbki krwi od 54 zdrowych kobiet $w$ wieku rozrodczym z prawidłowym cyklem menstruacyjnym. U wszystkich kobiet dokonano pomiaru masy ciała i wzrostu, a następnie obliczono wskaźnik masy ciała (BMI). Do oceny stężeń MMP-1, -3, -7, -8, -9, -12 i MMP-13 użyto zestawu Procarta Immunoassay. Stężenia estradiolu i progesteronu w surowicy mierzono metodą immunochemiluminescencji (32 w fazie proliferacyjnej i $20 \mathrm{w}$ fazie wydzielniczej cyklu menstruacyjnego). Obliczenia statystyczne uzyskanych danych wykonano za pomocą testów Pearsona, Spearmana i Kruskala-Wallisa.

Wyniki: Wykazano dodatnią korelację między stężeniami MMP-7, -8, -9, -12 i -13 a wartością wskaźnika BMI. U kobiet otyłych stężenia MMP były istotnie wyższe niż u kobiet z prawidłowym wskaźnikiem BMI. W grupie zdrowych, regularnie miesiączkujących kobiet przed menopauzą stężenia MMP nie były skorelowane ze stężeniami estradiolu ani progesteronu.

Wnioski: Wyniki badania wskazują, że masa ciała może wpływać na stężenie MMP w surowicy u kobiet z regularnymi cyklami menstruacyjnymi. (Endokrynol Pol 2019; 70 (1): 49-56)
\end{abstract}

Słowa kluczowe: MMP; otyłość; estradiol; progesteron

\section{Introduction}

Overweight and obesity are major epidemiological problems in many countries, irrespective of their economic position. Those conditions are accompanied by an increase in cardiovascular diseases, such as atherosclerosis, which is partially caused by remodelling of the extracellular matrix (ECM) [1]. Matrix metalloproteinases (MMPs) play a major role in this process, by regulating adipocyte development and remodelling [2]. 
MMPs are a family of protein enzymes. Their principal role is degradation of ECM at neutral $\mathrm{pH}$. Produced on site in tissues, they are important for the functioning and homeostasis of the vascular bed. They also have an immunomodulatory effect through the cytokines, chemokines, and growth factors [3].

MMPs are classified in groups according to their structure and substrate specificity [4]:

- interstitial collagenases: collagenase-1 (MMP-1), collagenase-2 (MMP-8), and collagenase-3 (MMP-13), which cleave native fibrillary collagen types I, II, and III;

- stromelysins: stromelysin-1 (MMP-3), stromelysin-2 (MMP-10), and stromelysin-3 (MMP-11), which degrade many components of basement membranes like fibronectin, laminin, and proteoglycan core protein;

- matrylysin-1 (MMP-7) and (MMP-26), which degrade basement membrane;

- gelatinases: gelatinase A (MMP-2) and gelatinase B (MMP-9), which degrade type IV collagen and collagen denatured after initial cleavage of collagenase; - metalloelastase (MMP-12), also known as macrophage elastase.

MMPs play an important role not only in physiological processes controlled by steroid hormones, such as cyclic degradation and renewal of human endometrium, embryo implantation, and trophoblast invasion, but also in the pathogenesis of benign and malignant tumours, formation of metastasis, and in immune diseases [5]. MMPs are present in ECM, plasma, and other body fluids. Under physiological conditions, their concentration in the blood is low.

Many factors have been reported that affect the production and activity of MMPs in the blood. It was found that high concentrations of circulating MMP-1 are associated with atherosclerotic plaque inflammation in response to factors including stress, oxidised low-density lipoproteins (LDL), and proinflammatory cytokines. The increase of MMP-1 is positively correlated with atherosclerotic lesions [6-8]. The increased levels of MMP-8 and MMP-9 in the blood of obese women are explained by the increment production by adipocytes [9]. However, there are high interindividual variations in the amount of MMP transcripts found both in fresh isolated human adipocytes and in in vitro tissue cultures. These data suggest that the synthesis of MMPs in adipocytes and their secretion into the blood remains under the control of still unknown modulating factors [10]. It seems that oestrogen may play a role in these processes, as it has been shown that oestrogens protect adipose tissue against oxidative stress [11]. Higher oestradiol levels during the menstrual cycle in overweight women, when compared to lean controls, suggest that there is a relation between its level and the concentration of MMPs in the blood [12].

The second hormone that affects the synthesis and secretion of MMPs through its immunomodulatory effect is progesterone. Animal studies on mice showed a local anti-inflammatory effect of progesterone in the uterine cervix, due to the effect of this hormone on neutrophils and monocytes, both known to release MMP-9 [13]. However, there are no studies evaluating the correlation of those hormones' serum concentration in obese women with MMP levels.

In obese people, the most commonly researched MMPs in the blood are MMP-1, -2, and -9. The present study investigated the activity of other MMPs as well. The results obtained from menstruating women were correlated with body weight as well as with oestradiol and progesterone concentrations, the two main hormones of which the concentrations change physiologically during the menstrual cycle. Describing dependencies between those factors can trigger further investigations on the vascular stability and pathomechanism of non-matrix disorders related to MMP concentrations [14].

The aim of the study was to evaluate the concentration of representatives of most types of MMPs: collagenases (MMP-1, -3, -8, -13), matrilysin (MMP-7), gelatinase (MMP-9), and metalloelastase (MMP-12) in serum of women in reproductive age in relation to their body mass index (BMI), age, and oestradiol and progesterone concentrations.

\section{Material and methods}

\section{Baseline characteristics}

The research was approved by the Bioethical Committee of the Medical University of Warsaw (KB/243/2012), and all participants signed informed consent before inclusion in the trial. Blood samples were taken from 54 healthy women with normal menstrual periods aged 25-40 years. In 32 women blood samples were taken in the proliferative (day 4-6) and in 20 women in the secretory (day 21-22) phase of the cycle. Weight and height of all women were measured, and BMI was calculated. Population was divided into three subgroups: BMI-1 with BMI $\leq 24.9 \mathrm{~kg} / \mathrm{m}^{2}$ (normoweight), BMI-2 with a BMI of $25-29.9 \mathrm{~kg} / \mathrm{m}^{2}$ (overweight), and BMI-3 with a BMI $\geq 30 \mathrm{~kg} / \mathrm{m}^{2}$ (obese). None of the participants was on hormonal treatment nor had they taken hormonal contraception prior to or during the research. Oestradiol and progesterone serum levels were assessed by immunochemiluminometric assay (ELISA, Elecsys, Cobase). As stated before samples were obtained from 32 patients in proliferative phase (day 4-6) and from 20 in secretory phase (day 21-22). 
Data was metiliculously described in Table 1 according to BMI groups. Part of each sample was frozen and stored at $-80^{\circ} \mathrm{C}$. After thawing, the concentration of MMP-1, MMP-3, MMP-7, MMP-8, MMP-9, MMP-12, and MMP-13 were evaluated using a Procarta immunoassay kit (Affymatrix, CA, USA) in accordance with the manufacturer's instruction. Multiplexes were run on a LABScan ${ }^{\mathrm{TM}} 100$ platform (Luminex Corp., Austin, TX, USA) equipped with Luminex ${ }^{\circledR} 100$ IS software. Samples were incubated with antibody-coated microspheres, which bind to specific MMPs. Microsphere-MMP complexes were washed and incubated with biotinylated MMP antibodies, which bind to MMPs present on the microspheres. A final incubation was performed in which phycoerythrin-labelled streptavidin was allowed to bind to biotinylated MMP antibodies present on microspheres. Microspheres were then loaded into a LABScan ${ }^{\mathrm{TM}} 100$ analyser, which quantifies the amount of phycoerythrin fluorescence present on each of the distinct microspheres. The median fluorescence intensity was used for subsequent calculations.

\section{Statistical analysis}

Pearson and Spearman tests were used to evaluate the BMI correlation with age, and hormone and metalloproteinases levels. The analysis of the results of metalloproteinase concentrations according to BMI was performed by the Kruskal-Wallis test. Statistical significance was considered when $\mathrm{p}<0.05$.

\section{Results}

The mean age of study group was $33( \pm 5.45)$ years with a mean BMI of $24.55( \pm 5.55) \mathrm{kg} / \mathrm{m}^{2}$. The mean serum oestradiol concentration was $102.16( \pm 84.03) \mathrm{pg} / \mathrm{ml}$ and progesterone concentration $4.88( \pm 5.58) \mathrm{ng} / \mathrm{ml}$. Mean $\mathrm{BMI}$ in the group of normal weight women was 21.6 $( \pm 1.89) \mathrm{kg} / \mathrm{m}^{2}$, in overweight $26.71( \pm 1.32) \mathrm{kg} / \mathrm{m}^{2}$, and in obese $34.35( \pm 6.81) \mathrm{kg} / \mathrm{m}^{2}$.

The mean concentrations of MMPs were: MMP-1 120.75 ( \pm 91.70) pg/ml, MMP-8 $82.90( \pm 64.14)$ pg/ml, MMP-13 4.90 ( \pm 3.71) pg/ml MMP-3 558.61 ( \pm 216.73) pg/ml, MMP-7 243.33 ( \pm 118.21) pg/ml, MMP-9 1790.29 $( \pm 2066.08)$ pg/ml, MMP-12 15.22 ( \pm 6.47) pg/ml. Biochemical markings were done in two groups, as previosly described (32 patients in day 4-6 and 20 patients in day 21-22). Complete data are presented in Table I. Descriptive statistics of participants are presented in Table I.

The results show that BMI was not correlated with age. A statistically significant correlation was found between BMI and: MMP-7 ( $<<0.05)$, MMP-8 ( $<<0.001)$, MMP-9 ( $p<0.01)$, and MMP-12 ( $<<0.05)$. The coefficient $(r)$ indicates that this interdependence can be defined as mean and positive (Fig. 1). In contrast, there was no correlation between previously mentioned MMPs and oestradiol or progesterone concentrations or the age of the examined women. The analysis of BMI correlations with age and concentration of the examined metalloproteinases is presented in Table II.

Table I. Clinical characteristics, hormones, and metalloproteinase levels of the study group

Tabela I. Charakterystyka kliniczna oraz stężenia hormonów i metaloproteinaz u uczestników badania

\begin{tabular}{|c|c|c|c|c|c|}
\hline \multicolumn{6}{|c|}{ Descriptive statistics } \\
\hline & Covariates & Count & Mean & Median & SD \\
\hline & Age (years) & 52 & 33.02 & 34.00 & 5.45 \\
\hline & BMI $\left[\mathrm{kg} / \mathrm{m}^{2}\right]$ & 52 & 24.55 & 22.98 & 5.55 \\
\hline & Oestradiol [pg/ml] & 52 & 102.16 & 79.57 & 84.03 \\
\hline & Progesterone [ng/ml] & 52 & 4.88 & 1.77 & 5.58 \\
\hline \multirow[t]{3}{*}{ Group BMI } & $\mathrm{BMI}=18.8-24.9\left[\mathrm{~kg} / \mathrm{m}^{2}\right]$ & 34 & 21.60 & 21.75 & 1.89 \\
\hline & $\mathrm{BMI}=25.0-29.9\left[\mathrm{~kg} / \mathrm{m}^{2}\right]$ & 10 & 26.71 & 26.97 & 1.32 \\
\hline & $\mathrm{BMI} \geq 30\left[\mathrm{~kg} / \mathrm{m}^{2}\right]$ & 8 & 34.35 & 31.97 & 6.81 \\
\hline \multirow[t]{3}{*}{ Collagenase } & MMP-1 [pg/ml] & 51 & 120.75 & 92.43 & 91.70 \\
\hline & MMP-8 [pg/ml] & 51 & 82.90 & 75.69 & 64.14 \\
\hline & MMP-13 [pg/ml] & 51 & 4.90 & 4.07 & 3.71 \\
\hline Stromelysin & MMP-3 [pg/ml] & 51 & 558.61 & 512.07 & 216.73 \\
\hline Matrilysin & MMP-7 [pg/ml] & 51 & 243.33 & 218.06 & 118.21 \\
\hline Gelatinase & MMP-9 [pg/ml] & 51 & 1790.29 & 750.42 & 2066.08 \\
\hline Metalloelastase & MMP-12 [pg/ml] & 51 & 15.22 & 13.81 & 6.47 \\
\hline
\end{tabular}

SD — standard deviation; BMI — body mass index; MMP — matrix metalloproteinase 

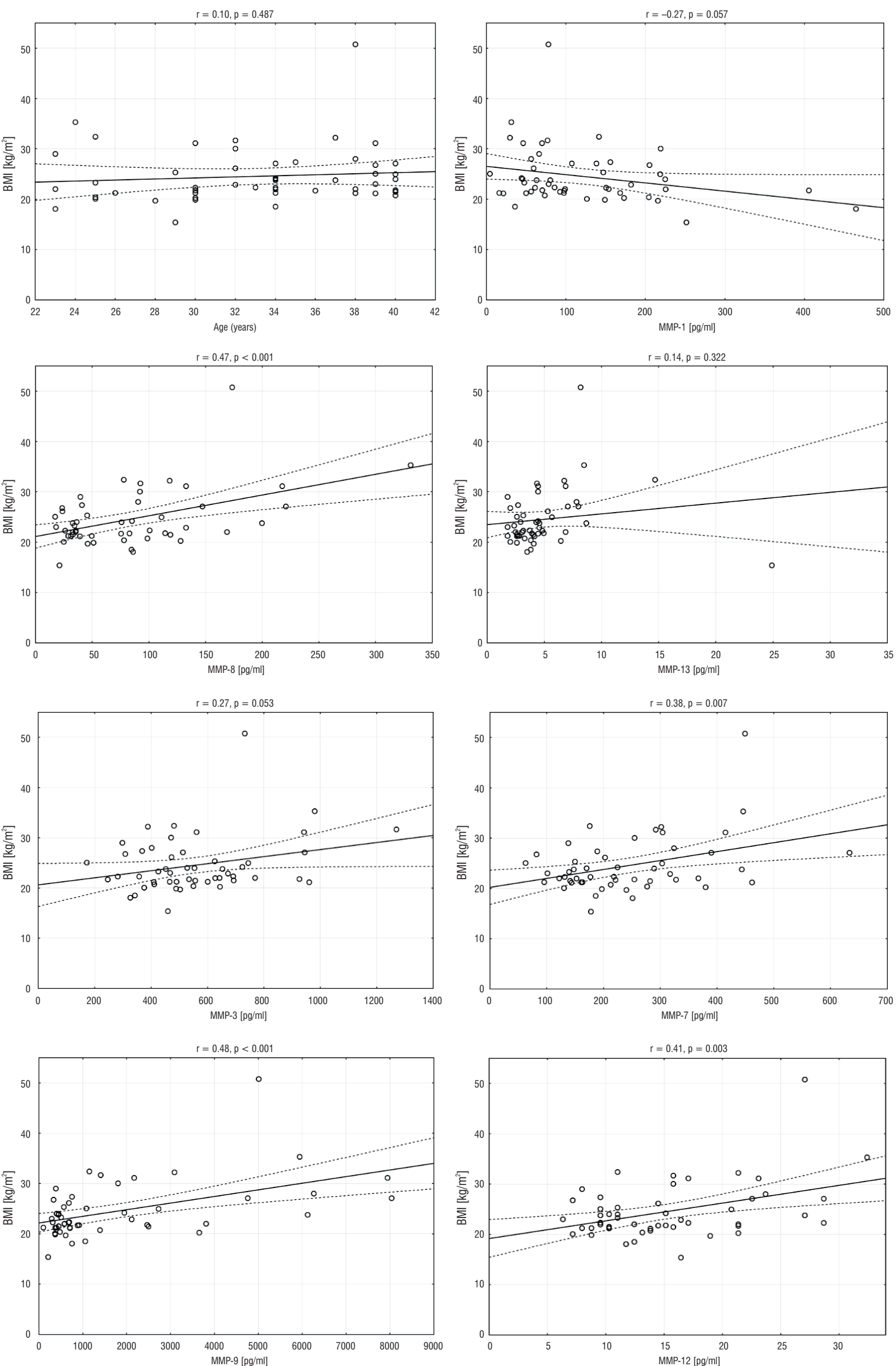

Figure 1. MMPs serum concentration versus body mass index (BMI). Pearson and Spearman rank correlation

Rycina 1. Stężenie MMP w surowicy a wartość wskaźnika masy ciała (BMI). Korelacja Pearsona i korelacja rang Spearmana 
Table II. Correlation between BMI, age, and MMPs serum concentration in the study group

Tabela II. Korelacja między BMI, wiekiem a stężeniem MMP w badanej grupie

\begin{tabular}{lcc}
\hline Pearson correlation & $\mathbf{r}$ & p-value \\
\hline Age (years) \& BMl $\left[\mathrm{kg} / \mathrm{m}^{2}\right]$ & 0.10 & 0.487 \\
\hline MMP-1 $[\mathrm{pg} / \mathrm{ml}]$ \& BMl $\left[\mathrm{kg} / \mathrm{m}^{2}\right]$ & -0.27 & 0.057 \\
\hline MMP-8 $[\mathrm{pg} / \mathrm{ml}]$ \& BMl $\left[\mathrm{kg} / \mathrm{m}^{2}\right]$ & 0.47 & $<0.001$ \\
\hline MMP-13 $[\mathrm{pg} / \mathrm{ml}]$ \& BMI $\left[\mathrm{kg} / \mathrm{m}^{2}\right]$ & 0.14 & 0.322 \\
\hline MMP-3 $[\mathrm{pg} / \mathrm{ml}]$ \& BMl $\left[\mathrm{kg} / \mathrm{m}^{2}\right]$ & 0.27 & 0.053 \\
\hline MMP-7 $\left[\mathrm{pg} / \mathrm{ml}\right.$ \& BMl $\left[\mathrm{kg} / \mathrm{m}^{2}\right]$ & 0.37 & 0.007 \\
\hline MMP-9 $[\mathrm{pg} / \mathrm{ml}]$ \& BMl $\left[\mathrm{kg} / \mathrm{m}^{2}\right]$ & 0.48 & $<0.001$ \\
\hline MMP-12 $[\mathrm{pg} / \mathrm{ml}]$ \& BMI $\left[\mathrm{kg} / \mathrm{m}^{2}\right]$ & 0.41 & 0.003 \\
\hline
\end{tabular}

$\mathrm{BMI}$ — body mass index; MMP — matrix metalloproteinase

Additionally, serum concentration of each of MMP was compared between the normoweight group (BMI-1) and the overweight group (BMI-2 and -3) using Kruskal-Wallis test (Fig. 2). MMP-7, MMP-8, MMP-9, MMP-12, and MMP-13 concentrations differed statistically significantly $(p<0.05)$ between these subgroups. The greatest differences were between the
BMI-1 and BMI-3 group (Table III). MMP-1 and MMP-3 concentrations did not differ significantly in the studied subgroups.

\section{Discussion}

The presented study reached its established aim by confirming the positive correlation between MMP-7, MMP-8, MMP-9, MMP-12, and MMP-13 levels and BMI. Significantly higher concentrations of MMP-7, MMP-8, MMP-9, MMP-12, and MMP-13 were found especially in obese women compared to lean controls. In healthy, regularly menstruating, premenopausal women MMPs in blood did not correlate with oestradiol and progesterone concentrations.

\section{$M M P-1$}

MMP-1 is linked to the development of atherosclerosis. It is responsible for collagen degradation in the vascular wall, and it influences platelet activation $[15,16]$. The lack of correlation between serum MMP-1 and BMI was probably due to the fact that the study was conducted in healthy women, without vascular dysfunction.
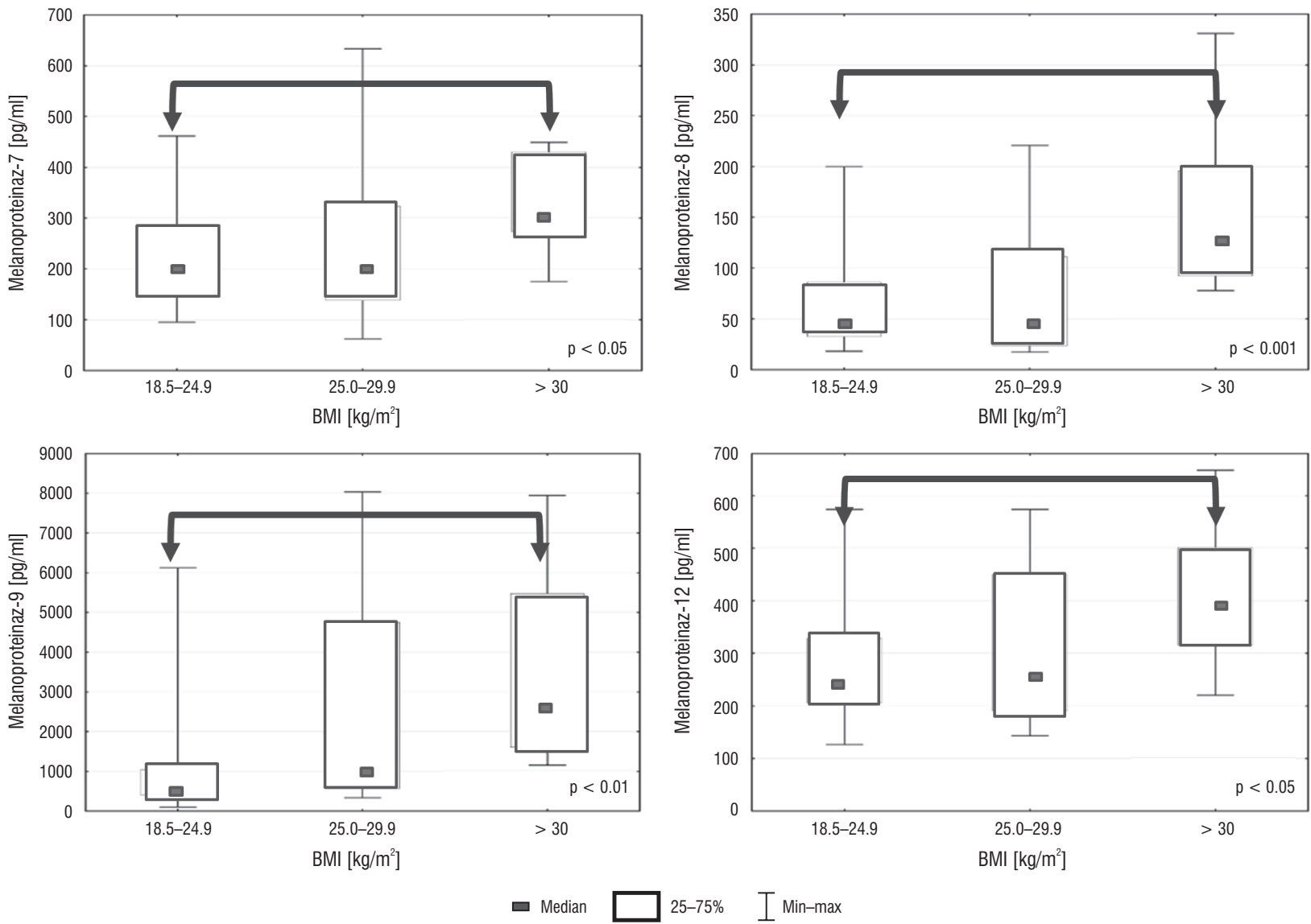

Figure 2. MMPs serum concentration in three subgroups of women. Kruskal-Wallis test Rycina 2. Stężenie MMP w surowicy w trzech podgrupach kobiet. Test Kruskala-Wallisa 
Table III. Results of MMPs serum concentration in three subgroups of patients: BMI-1 with BMI $\leq 24.9 \mathrm{~kg} / \mathrm{m}^{2}, B M I-2$ with BMI 25-29.9 $\mathrm{kg} / \mathrm{m}^{2}$, and BMI-3 with BMI $\geq 30 \mathrm{~kg} / \mathrm{m}^{2}$

Tabela III. Wyniki badania stężenia MMP w trzech podgrupach pacjentek: BMI-1 z BMI $\leq 24.9 \mathrm{~kg} / \mathrm{m}^{2}$, BMI-2 $z$ BMI $25-29.9 \mathrm{~kg} / \mathrm{m}^{2}$ i BMI-3 $z$ BMI $\geq 30 \mathrm{~kg} / \mathrm{m}^{2}$

\begin{tabular}{|c|c|c|c|}
\hline Subgroups & $\begin{array}{l}\text { BMI-1 } \\
\text { vs. BMI-2 }\end{array}$ & $\begin{array}{c}\text { BMI-2 } \\
\text { vs. BMI-3 }\end{array}$ & $\begin{array}{c}\text { BMI-1 } \\
\text { vs. BMI-3 }\end{array}$ \\
\hline $\begin{array}{l}\text { MMP-1 } \\
\text { concentration }\end{array}$ & \multicolumn{3}{|c|}{ Kruskal-Wallis test: $\mathrm{H}=1.61 \mathrm{p}=0.431$} \\
\hline Z & 0.13 & 0.99 & 1.29 \\
\hline$p$-value & 1.009 & 0.999 & 0.599 \\
\hline $\begin{array}{l}\text { MMP-3 } \\
\text { concentration }\end{array}$ & \multicolumn{3}{|c|}{ Kruskal-Wallis test: $\mathrm{H}=4.05, \mathrm{p}=0.121$} \\
\hline Z & 0.98 & 2.00 & 1.51 \\
\hline$p$-value & 0.988 & 0.136 & 0.391 \\
\hline $\begin{array}{l}\text { MMP-7 } \\
\text { concentration }\end{array}$ & \multicolumn{3}{|c|}{ Kruskal-Wallis test: $\mathrm{H}=\mathbf{6 . 3 5}, \mathrm{p}=\mathbf{0 . 0 4 2}$} \\
\hline Z & 0.18 & 1.93 & 2.49 \\
\hline$p$-value & 1.000 & 0.160 & 0.038 \\
\hline $\begin{array}{l}\text { MMP-8 } \\
\text { concentration }\end{array}$ & \multicolumn{3}{|c|}{ Kruskal-Wallis test: $\mathrm{H}=\mathbf{9 . 4 3 , p}=0.009$} \\
\hline Z & 0.09 & 2.44 & 3.02 \\
\hline$p$-value & 1.000 & 0.044 & 0.008 \\
\hline $\begin{array}{l}\text { MMP-9 } \\
\text { concentration }\end{array}$ & \multicolumn{3}{|c|}{ Kruskal-Wallis test: $H=11.36, p=0.003$} \\
\hline Z & 1.53 & 1.53 & 3.26 \\
\hline$p$-value & 0.379 & 0.366 & 0.003 \\
\hline $\begin{array}{l}\text { MMP-12 } \\
\text { concentration }\end{array}$ & \multicolumn{3}{|c|}{ Kruskal-Wallis test: $H=6.31, p=0.043$} \\
\hline Z & 0.34 & 1.82 & 2.50 \\
\hline$p$-value & 1.000 & 0.205 & 0.037 \\
\hline $\begin{array}{l}\text { MMP-13 } \\
\text { concentration }\end{array}$ & \multicolumn{3}{|c|}{ Kruskal-Wallis test: $\mathbf{H}=\mathbf{8 . 8 5}, \mathrm{p}=\mathbf{0 . 0 1 2}$} \\
\hline Z & 0.59 & 2.02 & 2.97 \\
\hline $\mathrm{p}$-value & 1.000 & 0.129 & 0.009 \\
\hline
\end{tabular}

\section{MMP-3}

It was not found that the presence of MMP-3 in the blood was influenced by body weight or oestradiol and progesterone concentrations in our study. Probably because MMP-3 is secreted only in a state of severe illness. Previous studies have shown the role of MMP-3 in the activation of gelatinase-A (MMP-2) and gelatinase-B (MMP-9) in the wall of damaged vessels [17]. The importance of MMP-3 has been demonstrated in the pathogenesis of heart failure [18], development of lung diseases [19], and rheumatoid arthritis [20]. In these conditions MMP-3 levels were elevated both in the affected tissue and in serum.

\section{MMP-7}

Our research, according to our best knowledge, is the first clinical study that shows the association of obesity and MMP-7 level. This finding may explain the significance of excess body weight in the development of atherosclerotic disease. Substrates for MMP-7 are:

- apolipoprotein C-II (apoC-II), which is cofactor of lipoprotein lipase (LPL) and a component of very low-density lipoproteins and chylomicrons;

- apolipoprotein A-IV (apoA-IV) [21].

Cleavage of apoC-II significantly lowers LPL activity, resulting in hydrolysis of triglycerides in the blood and transfer of fatty acids to tissues. Cleavage of apoA-IV mediated by MMP-7 results in loss of intrinsic anti-oxidant activity and has pathological implications in the development of hyperlipidaemia and atherosclerosis [21].

\section{MMP-8}

MMP-8 (neutrophil collagenase) is involved in the pathogenesis of chronic inflammatory disorders, such as cardiovascular diseases, lung diseases, and cancer [22]. Aquilante et al. demonstrated higher serum MMP-8 levels in patients with metabolic syndrome even in the absence of cardiovascular disease and diabetes [23]. The results of our study indicate a positive correlation between serum MMP-8 and BMI. MMP-8 serum concentration in overweight women was significantly higher than those with normal body weight. However, the opposite results were shown by Andrade et al. [9]. He explained that the decrease of plasma MMP-8 concentration was by mechanisms not related to neutrophil activation, such as negative regulation of MMP-8 expression by transforming growth factor beta 1 . The authors also suggest that fatty tissue may not synthesise MMP-8 in such quantities as to be detected in the blood, which is contrary to our findings.

\section{MMP-9}

MMP-9 is the major determinant of collagen degradation. It is the most commonly studied enzyme so far. The results of our study confirm the findings of other authors, who showed higher MMP-9 levels in obese compared to lean women $[9,24]$. Adipose tissue is an important key regulator of adipocyte differentiation [10]. The increase in MMP-9 circulating level in the population aged over 45 years, even without signs of coronary artery disease, is correlated with increased cardiovascular risk [25].

\section{MMP-12}

MMP-12 concentration was positively correlated with BMI in the osteochondral unit and adipose tissue [26]. In adipose tissue it is produced by macrophages and 
preadipocytes [27]. It has also been found in atherosclerotic plaque, where it is responsible for the degradation of elastic fibres [28]. Our results indicate that also the blood concentration of MMP-12 is statistically higher in overweight and obese women compared to lean women. However, whether this correlation is the result of increased production in adipose tissue or changes in vascular walls requires further research.

\section{MMP-13}

MMP-13 is more efficient in cleaving type II collagen than types I and III [29]. The positive correlation between BMI and MMP-13 in our study indicates that obesity is an independent factor that increases blood MMP-13 levels. In obese people adipose tissue may be the source of excessive MMP-13 production. MMP-13 inhibitors have been shown to inhibit adipogenesis and prevent diet-induced obesity in mice [30]. In humans, increased levels of MMP-13 have been reported with atheroma and developing heart disease [31]. This finding could lead to developing new ways of tackling obesity in humans.

There is no relationship between the concentration of this MMP and the concentration of oestradiol and progesterone in the blood. A strong link between oestradiol and age and MMP-13 concentrations was reported only in murine skin squamous cell carcinoma cases [32].

\section{Conclusions}

In conclusion, despite the small number of subjects included in the study, we found significant differences in MMP-7, MMP-8, MMP-9, MMP-12, and MMP-13 serum concentrations between lean and overweight women. Those findings suggest that these MMPs may play a role in the pathogenesis of body mass-related diseases. However, the exact mechanisms are still unclear, and further studies are needed to clarify the problem.

\section{Authors contribution}

G. Grzechocinska - performed study, analysed data, wrote manuscript; F. Dabrowski - performed study, analysed data, wrote manuscript; J. Sierdzinski - analysed data; A. Cyganek — performed study, analysed data; M. Wielgos — analysed data, wrote manuscript.

\section{Conflict of interests}

The authors declare no conflict of interest.

\section{References}

1. Van Gaal LF, Mertens IL, De Block CE. Mechanisms linking obesity with cardiovascular disease. Nature. 2006; 444(7121): 875-880, doi: 10.1038/nature05487, indexed in Pubmed: 17167476.
2. Kujawska-Łuczak M, Suliburska J, Markuszewski L, et al. The effect of L-arginine and ascorbic acid on the visceral fat and the concentrations of metalloproteinases 2 and 9 in high-fat-diet rats. Endokrynol Pol. 2015; 66(6): 526-532, doi: 10.5603/EP.2015.0065, indexed in Pubmed: 26662652.

3. Van Lint P, Libert C. Chemokine and cytokine processing by matrix metalloproteinases and its effect on leukocyte migration and inflammation. J Leukoc Biol. 2007; 82(6): 1375-1381, doi: 10.1189/jlb.0607338, indexed in Pubmed: 17709402.

4. Nagase $\mathrm{H}$, Visse $\mathrm{R}$, Murphy $\mathrm{G}$. Structure and function of matrix metalloproteinases and TIMPs. Cardiovasc Res. 2006; 69(3): 562-573, doi: 10.1016/j.cardiores.2005.12.002, indexed in Pubmed: 16405877.

5. Sikora-Szubert A, Kowalska-Koprek U, Karowicz-Bilinska A. [The analysis of selected biochemical parameters concentration in pregnant women with idiopathic edema of the lower limbs--preliminary report]. Ginekol Pol. 2012; 83(9): 660-664.

6. Wu YW, Kao HL, Chen MF, et al. Characterization of plaques using 18F-FDG PET/CT in patients with carotid atherosclerosis and correlation with matrix metalloproteinase-1. J Nucl Med. 2007; 48(2): 227-233, indexed in Pubmed: 17268019.

7. Newby AC. Metalloproteinase expression in monocytes and macrophages and its relationship to atherosclerotic plaque instability. Arterioscler Thromb Vasc Biol. 2008; 28(12): 2108-2114, doi: 10.1161/ATVBAHA.108.173898, indexed in Pubmed: 18772495.

8. Lehrke M, Greif M, Broedl UC, et al. MMP-1 serum levels predict coronary atherosclerosis in humans. Cardiovasc Diabetol. 2009; 8: 50, doi: 10.1186/1475-2840-8-50, indexed in Pubmed: 19751510.

9. Andrade VL, Petruceli E, Belo VA, et al. Evaluation of plasmatic MMP-8, MMP-9, TIMP-1 and MPO levels in obese and lean women. Clin Biochem. 2012; 45(6): 412-415, doi: 10.1016/j.clinbiochem.2012.01.008, indexed in Pubmed: 22285381

10. Bouloumié A, Sengenès C, Portolan G, et al. Adipocyte produces matrix metalloproteinases 2 and 9: involvement in adipose differentiation. Diabetes. 2001; 50(9): 2080-2086, indexed in Pubmed: 11522674.

11. Taskiran D, Evren V. Estradiol protects adipose tissue-derived stem cells against $\mathrm{H}(2) \mathrm{O}(2)$-induced toxicity. J Biochem Mol Toxicol. 2012; 26(8): 301-307, doi: 10.1002/jbt.21421, indexed in Pubmed: 22696422

12. Emaus A, Espetvedt S, Veierød MB, et al. 17-beta-estradiol in relation to age at menarche and adult obesity in premenopausal women. Hum Reprod. 2008; 23(4): 919-927, doi: 10.1093/humrep/dem432, indexed in Pubmed: 18227106

13. Furcron AE, Romero R, Plazyo O, et al. Vaginal progesterone, but not 17 -hydroxyprogesterone caproate, has antiinflammatory effects at the murine maternal-fetal interface. Am J Obstet Gynecol. 2015; 213(6): 846 e1-846.e19, doi: 10.1016/j.ajog.2015.08.010, indexed in Pubmed: 26264823.

14. Martínez A, Oh HR, Unsworth EJ, et al. Matrix metalloproteinase-2 cleavage of adrenomedullin produces a vasoconstrictor out of a vasodilator. Biochem J. 2004; 383(Pt. 3): 413-418, doi: 10.1042/BJ20040920, indexed in Pubmed: 15307819.

15. Cavusoglu E, Marmur J, Hegde S, et al. Relation of baseline plasma MMP-1 levels to long-term all-cause mortality in patients with known or suspected coronary artery disease referred for coronary angiography. Atherosclerosis. 2015; 239(1): 268-275, doi: 10.1016/j.atherosclerosis.2015.01.003, indexed in Pubmed: 25635325

16. Austin KM, Covic L, Kuliopulos A. Matrix metalloproteases and PAR1 activation. Blood. 2013; 121(3): 431-439, doi: 10.1182/blood-2012-09-355958, indexed in Pubmed: 23086754.

17. Lijnen HR, Silence J, Van Hoef B, et al. Stromelysin-1 (MMP-3)-independent gelatinase expression and activation in mice. Blood. 1998; 91(6): 2045-2053, indexed in Pubmed: 9490689.

18. Tziakas DN, Chalikias GK, Papaioakeim M, et al. Comparison of levels of matrix metalloproteinase- 2 and -3 in patients with ischemic cardiomyopathy versus nonischemic cardiomyopathy. Am J Cardiol. 2005; 96(10): 1449-1451, doi: 10.1016/j.amjcard.2005.06.096, indexed in Pubmed: 16275197.

19. Kwon S, Weiden MD, Echevarria GC, et al. Early elevation of serum MMP-3 and MMP-12 predicts protection from World Trade Center-lung injury in New York City Firefighters: a nested case-control study. PLoS One. 2013; 8(10): e76099, doi: 10.1371/journal.pone.0076099, indexed in Pubmed: 24146820

20. Catrina AI, Lampa J, Ernestam S, et al. Anti-tumour necrosis factor (TNF)-alpha therapy (etanercept) down-regulates serum matrix metalloproteinase (MMP)-3 and MMP-1 in rheumatoid arthritis. Rheumatology (Oxford). 2002; 41(5): 484-489, indexed in Pubmed: 12011369

21. Park JiY, Park JH, Jang W, et al. Apolipoprotein A-IV is a novel substrate for matrix metalloproteinases. J Biochem. 2012; 151(3): 291-298, doi: 10.1093/jb/mvr137, indexed in Pubmed: 22170214.

22. Väyrynen JP, Vornanen J, Tervahartiala T, et al. Serum MMP-8 levels increase in colorectal cancer and correlate with disease course and inflammatory properties of primary tumors. Int J Cancer. 2012; 131(4) E463-E474, doi: 10.1002/ijc.26435, indexed in Pubmed: 21918979. 
23. Aquilante CL, Beitelshees AL, Zineh I. Correlates of serum matrix metalloproteinase-8 (MMP-8) concentrations in nondiabetic subjects without cardiovascular disease. Clin Chim Acta. 2007; 379(1-2): 48-52, doi: 10.1016/j.cca.2006.12.006, indexed in Pubmed: 17254561.

24. Kosmala W, Plaksej R, Przewlocka-Kosmala M, et al. Matrix metalloproteinases 2 and 9 and their tissue inhibitors 1 and 2 in premenopausal obese women: relationship to cardiac function. Int I Obes (Lond). 2008; 32(5): 763-771, doi: 10.1038/sj.ijo.0803794, indexed in Pubmed: 18197181.

25. Garvin P, Nilsson L, Carstensen J, et al. Circulating matrix metalloproteinase-9 is associated with cardiovascular risk factors in a middle-aged normal population. PLoS One. 2008; 3(3): e1774, doi: 10.1371/journal. pone.0001774, indexed in Pubmed: 18335048.

26. Kaspiris A, Khaldi L, Chronopoulos E, et al. Macrophage-specific metalloelastase (MMP-12) immunoexpression in the osteochondral unit in osteoarthritis correlates with BMI and disease severity. Pathophysiology. 2015; 22(3): 143-151, doi: 10.1016/j.pathophys.2015.06.001, indexed in Pubmed: 26126948.

27. Chavey C, Mari B, Monthouel MN, et al. Matrix metalloproteinases are differentially expressed in adipose tissue during obesity and modulate adipocyte differentiation. J Biol Chem. 2003; 278(14): 11888-11896, doi: 10.1074/jbc.M209196200, indexed in Pubmed: 12529376.
28. Halpert I, Sires UI, Roby JD, et al. Matrilysin is expressed by lipid-laden macrophages at sites of potential rupture in atherosclerotic lesions and localizes to areas of versican deposition, a proteoglycan substrate for the enzyme. Proc Natl Acad Sci U S A. 1996; 93(18): 9748-9753, indexed in Pubmed: 8790402

29. Howes JM, Bihan D, Slatter DA, et al. The recognition of collagen and triple-helical toolkit peptides by MMP-13: sequence specificity for binding and cleavage. J Biol Chem. 2014; 289(35): 24091-24101, doi: 10.1074/jbc.M114.583443, indexed in Pubmed: 25008319.

30. Shih CLM, Ajuwon KM. Inhibition of MMP-13 prevents diet-induced obesity in mice and suppresses adipogenesis in 3T3-L1 preadipocytes. Mol Biol Rep. 2015; 42(7): 1225-1232, doi: 10.1007/s11033-015-3861-2, indexed in Pubmed: 25682268.

31. Suzuki H, Kusuyama T, Sato R, et al. Elevation of matrix metalloproteinases and interleukin- 6 in the culprit coronary artery of myocardial infarction. Eur J Clin Invest. 2008; 38(3): 166-173, doi: 10.1111/j.1365-23 62.2007.01919.x, indexed in Pubmed: 18257779.

32. Meides A, Gutschalk CM, Devel L, et al. Effects of selective MMP-13 inhibition in squamous cell carcinoma depend on estrogen. Int J Cancer. 2014; 135(12): 2749-2759, doi: 10.1002/ijc.28866, indexed in Pubmed: 24676718. 